\title{
Optimization of fat yield of bambangan (Mangifera pajang) kernel using response surface methodology and its antioxidant activities
}

\begin{abstract}
The objectives of this study are to optimize the extraction of fat from bambangan kernel using response surface methodology and to determine its antioxidant activities and total phenolic contents (TPC). Bambangan kernel was also investigated to determine proximate and amino acids in a pursuit to identify an innovative fruit which could be exploited in other food applications. Results for proximate compositions of bambangan kernel indicates moisture contents of $8.9 \%$, crude protein contents of $4.1 \%$, ash contents of $2.8 \%$, and carbohydrate contents of $72.9 \%$ on dry weight basis. The highest fat yield of bambangan kernel was found to be $11.0 \%$ with optimum parameters at solvent volume of $329.7 \mathrm{ml}$ (nhexane), samples weight of $27.0 \mathrm{~g}$, and extraction time of $7.6 \mathrm{~h}$. 2,2-Diphenyl-1-picrylhydrazyl (DPPH) free radical scavenging ability of bambangan kernel powder and fat were found to be $60.6 \pm 2.1$ and $35.2 \pm 2.1 \mathrm{mg}$ TEAC/100 $\mathrm{g}$, respectively. Moreover, the ferric reducing antioxidant power (FRAP) of bambangan kernel powder and fat were 150.6 \pm 2.4 and $119.0 \pm 6.3 \mathrm{mM} / 100 \mathrm{~g}$, respectively. The TPC of bambangan kernel powder was $118.6 \pm 1.9 \mathrm{mg}$ GAE$/ \mathrm{g}$, whereas kernel fat was $94.1 \pm 2.1 \mathrm{mg}$ GAE/g. The DPPH radical scavenging and FRAP activities showed a strong correlation with TPC in both bambangan kernel powder and fat. The high TPC of bambangan kernel and its fat indicated that the kernels should be further utilized or processed to other food, nutraceutical or pharmaceutical products instead of discarded as waste.
\end{abstract}

Keyword: Bambangan kernel; Bambangan kernel fat; RSM; Antioxidant activities; Total phenolic contents 